Permanent link for this document : https://doi.org/10.33367/tribakti.v31i2.1232

\title{
Pandemi dalam Worldview Islam; Dari Konsepsi ke Konspirasi
}

\author{
Abdullah Muslich Rizal Maulana \\ Program Studi Agama-Agama Fakultas Ushuluddin Universitas Darussalam Gontor \\ amrizalm@unida.gontor.ac.id
}

\begin{abstract}
In order to face the challenge of the COVID-19 Pandemic, Muslims are demanded to conduct Health Protocols following the Worldview of Islam. This paper will re-comprehend the concept of Pandemic in accordance with the Worldview of Islam through a reflection of the Islamic Theological and Civilization aspect before continued with the discussion about Conspiracy Theories around The COVID-19 Pandemic and finally ended with a brief note regarding 'New Normal' code. This paper successfully concluded several convictions are: First, Pandemic is classified as Sunnatullah determined by God; Second, Muslims should carry out Health Protocols based on the Worldview of Islam and Third, anticipated Conspiracy Theories appears during Pandemic especially COVID-19
\end{abstract}

Keywords: Pandemic COVID-19, Worldview of Islam, Conception to Conspiracy

\begin{abstract}
Abstrak
Guna menghadapi tantangan Pandemi COVID-19, Muslim dituntut untuk melaksanakan protokol-protokol kesehatan sesuai dengan Worldview atau 'Pandangan Hidup' Islam. Makalah ini akan meneliti kembali konsep Pandemi dengan Worldview Islam yang tersusun atas refleksi akan aspek Teologis dan Peradaban Islam, sebelum kemudian dilanjutkan dengan pembahasan terkait teori-teori Konspirasi yang mengitari Pandemi COVID-19, dan akhirnya ditutup dengan catatan kecil akan Kebijakan 'New Normal'. Makalah ini berhasil menyimpulkan sejumlah hal di antaranya, Pandemi adalah sunnatullah yang telah ditetapkan; Kedua, Umat Islam wajib melaksanakan protokoler hidup sehat berlandaskan Pandangan Hidup Islam dan Ketiga, mengantisipasi teoriteori konspirasi yang muncul selama Pandemi terutama COVID-19.
\end{abstract}

Kata Kunci: Pandemi COVID-19, Worldview Islam, Konsepsi ke Konspirasi

\section{Pendahuluan}

Secara umum Pandemi (Pandemic) dapat dipahami sebagai penyebaran penyakit dalam skala besar, jangka panjang, dan mempengaruhi masyarakat dalam skala global. ${ }^{1}$ Pandemi berbahaya tidak hanya karena berdasarkan penyebaran atau jumlah korban yang menjadi korban, namun juga karena menular. Sebagai contoh, Kanker bertanggung jawab atas hampir 9 juta penderitanya di tahun 2015, namun dia tidak dianggap sebagai

${ }^{1}$ Miquel Portaq, Sander Greendland, and John M. Last, eds., Dictionary of Epidemiology, 5th ed. (New York: Oxford University Press, 2008), 179.

Tribakti: Jurnal Pemikiran Keislaman

Volume 31, Nomor 3, Juli 2020 
Pandemi karena ia tidak menular. Pandemi juga berbeda dengan Epidemi (Epidemic) yang hanya berlangsung dalam jangka waktu singkat, sementara Pandemi bisa terjadi dalam durasi yang cukup lama. ${ }^{2}$

Dalam tradisi studi agama-agama, setiap konsep yang diformulasikan semestinya merujuk kepada pandangan hidup (Worldview/ Weltanschauung) peradaban tersebut. Hal ini dikarenakan Worldview memiliki tugas penting guna membentuk cara pandang manusia dalam menyikapi realitas. Dalam tradisi Barat, ia dikembangkan di tangan Immanuel Kant (1724-1804), ${ }^{3}$ Ninian Smart (1927-2001), ${ }^{4}$ hingga Thomas Kuhn (19221996); ${ }^{5}$ sementara dalam tradisi Islam, konsepsi Worldview dikembangkan dari mulai Sayyid Qutb (1906-1966), ${ }^{6}$ Al-Maududi (1903-1979), ${ }^{7}$ Toshihiko Izutsu (19141997) ${ }^{8}$,dan Syed Muhammad Naquib al-Attas (1931-). ${ }^{9}$

Worldview mengonsepsikan setiap elemen kunci dari setiap agama hingga memiliki identitas yang khas berdasarkan tradisi keagamaannya. Dalam catatan Smart, misalnya, memahami Worldview memiliki tiga urgensi: Pertama, Worldview adalah bahan yang vital dalam perjalanan pengalaman manusia yang beragam; Kedua, Worldview berperan dalam menangkap makna-makna dan nilai-nilai dari pluralnya kebudayaan dunia hari ini, di mana makna dan nilai tersebut, bersumber dari Worldview agama dan/ atau ideologi masing-masing yang dianut; Ketiga, individu manusia secara fitrahnya akan berupaya membangun gambaran akan realitas yang koheren dan lengkap. Di sini, Worldview bertugas sebagai 'kaca perbandingan' dalam melihat gagasangagasan dan praktik-praktik kehidupan yang canggih di setiap kebudayaan dan peradaban manusia. ${ }^{10}$

\footnotetext{
${ }^{2}$ Principles of Epidemiology in Public Health Practice An Introduction to Applied Epidemiology and Biostatistics $O$, 3rd ed. (Georgia: U.S. Department of Health and Human Services Centers for Disease Control and Prevention (CDC) Office of Workforce and Career Development (OWCD) Career Development Division (CDD), 2012), 6-3.

${ }^{3}$ Immanuel Kant, Critique of Judgment, ed. Werner S. Pluhar (Indianapolis: Hackett Publishing Company, 1987), 111-112.

${ }^{4}$ Ninian Smart, The World's Religions (Cambridge: Cambridge University Press, 1998), 10. Press, 1996).

5 Thomas S. Kuhn, The Structure of Scientific Revolutions (Chicago: The University of Chicago

${ }^{6}$ Sayyid Quthb, Khasaaish Al-Tashawwur al-Islaamiy (Dar El Shorouk, n.d.).

${ }^{7}$ Sayyid Abul A'la al-Mawdudi al-Maududi, Islamic Way of LIfe (Riyadh: International Islamic Publishing House, 1997).

${ }^{8}$ Toshihiko Izutsu, Ethico-Religious Concepts in the Qur'an (Montreal: McGill-Queen's University Press, 2002), 12.

${ }^{9}$ Syed Muhammad Naquib al-Attas, Prolegomena to The Metaphysics of Islam (Kuala Lumpur: International Institute of Islamic Thought and Civilization (ISTAC), 1995), 1.

${ }^{10}$ Smart, The World's Religions, 10.
} 
Penelitian ini secara khusus akan merefleksikan Pandemi sesuai dengan model pendekatan Worldview yang digagas oleh Syed Muhammad Naquib al-Attas. Menurut alAttas, Worldview dalam perspektif Islam adalah “...the vision of reality and truth that appears before the mind's eye revealing what existence is all about; for it is the world of experience in its totality that Islam is projecting. "11 Guna mencapai itu, Worldview Islam diderivasi dari al-Qur'an dan al-Sunnah sebagai sumber paling otoritatif dalam Islam, kemudian diafirmasi melalui prinsip-prinsip intuitif dan intelektual yang dibangun dalam tradisi intelektual Islam. ${ }^{12}$ Konsekuensi yang lahir dari pendekatan Worldview adalah 'rekonstruksi' atau 'konseptualisasi' makna Pandemi secara lebih luas sesuai dengan framework yang sudah tersebut di atas. Makalah ini akan mengantarkan Diskusi kepada bagaimana semestinya seorang Muslim mampu bersikap dalam menghadapi Pandemi berdasarkan Pandangan Hidup Islam, terutama kaitannya dengan Covid-19.

\section{Metode}

Penelitian ini akan mencoba mengkonepsikan ulang 'Pandemi' dalam kerangka analisis Worldview atau Pandangan Hidup Islam. Guna mencapai itu, peneliti menggunakan metode 'Analisis Diskursus' (Discourse Analysis). Metode ini, sebagaimana diafirmasi oleh Titus Hjelm, mengkaji bagaimana identitas-identitas, hubungan-hubungan, kepercayaan-kepercayaan, serta sistem-sistem pengetahuan dibangun dalam penggunaan bahasa menjadi sebuah terminologi. ${ }^{13}$ Terminologi Pandemi menjadi titik fokus yang didiskusikan dalam penelitian ini berdasarkan konsepsinya yang dibangun dalam Pandangan Hidup (Worldview) Islam.

\section{Hasil dan Pembahasan}

\section{Konsep Pandemi dalam Worldview Islam.}

Dalam Worldview Islam, paling tidak ada dua buah konsep yang harus diteliti guna memahami Pandemi: Pertama, Pandemi sebagai 'Musibah'. Musibah diderivasi dari Bahasa Arab, yang berakar kata dari 'Ashaaba' (أصاب). Kata ini memiliki akar kata yang sama dengan Shawaab صواب) yang artinya benar; atau secara harfiah maknanya adalah ‘lawan/ kebalikan dari kesalahan' (ضد الخطأ) . Secara konseptual, Musibah dalam

${ }_{11}$ al-Attas, Prolegomena to The Metaphysics of Islam, 2.

12 al-Attas, 4.

${ }^{13}$ Michael Stausberg and Steven Engler, eds., The Routledge Handbook of Research Methods in The Study of Religion (London; New York: Routledge, 2011), 134.

Tribakti: Jurnal Pemikiran Keislaman

Volume 31, Nomor 2, Juli 2020 
pandangan hidup Islam adalah 'sudah pasti benar' sesuai dengan sunnatullah yang terjadi hanya dengan izin Allah semata. ${ }^{14}$ Hal ini sesuai dengan Hadist Rasulullah Shallallahu 'alayhi wa sallam:

$$
\text { أَصَابَ اللهُ بِكَ }
$$

Menurut penjelasan Qadhi Iyadh, hadist tersebut bermakna bahwa Allah telah menetapkan jalan petunjuk dan kebenaran (Shawaab). ${ }^{15}$ Artinya, 'musibah' itu diturunkan tidaklah lain sebagai bagian dari sebuah pemandu perjalanan kehidupan manusia agar selalu berada dalam jalan 'yang benar'. 'Musibah' juga memiliki dimensi kebaikan -petunjuk dan kebenaran- yang dikaruniakan kepada manusia sepanjang hidupnya ( 'Maa ashaabaka min al-Dahri' (ما أصابك من الدهر)); ${ }^{16}$ Musibah, dalam konsepsi ini, telah diberikan oleh Allah sesuai dengan 'kekuatan' dan 'kemampuan' umat itu sendiri untuk berupaya.$^{17}$

'Ketetapan' atau izin Allah atas terjadinya suatu musibah juga dapat kita refleksikan dari al-Qur'an Surat al-Hadid (57) ayat 22:

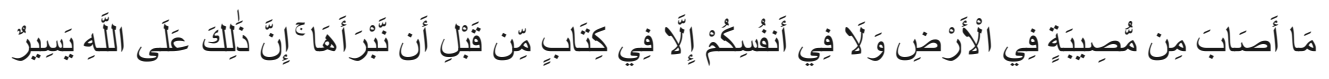

Menurut Ibn Katsir, ayat menunjukkan bahwa segala sesuatu yang terjadi di alam semesta maupun terjadi pada manusia telah ditetapkan bahkan sebelum diturunkannya Khalifah; yakni Nabi Adam. Artinya, fenomena-fenomena yang terjadi itu bahkan sudah ada sebelum kelahiran manusia pertama. ${ }^{18}$ Imam al-Thabary bahkan lebih detail menyatakan bahwa musibah itu termasuk di antaranya, laparnya manusia, keringnya lahan mereka, termasuk sakit yang mendera itu sudah ditetapkan Allah. ${ }^{19}$

Kedua, Pandemi juga patut dipahami sebagaimana adanya yaitu sakit atau 'Maradh' (مرض). Imam Bukhari dalam Sahih-nya mencantumkan sejumlah hadist yang khusus terkait dengan sakit di Kitaab al-Maradh. Di bagian awal Kitab ini, Imam

${ }^{14}$ Abu al-Fadhl Jamaal al-Diin Muhammad Muhammad ibn Mukrim ibn Manzhuur, Lisaan Al'Arab, Vol. 1, 15 vols. (Beirut: Daar Shaadir, 2010), 535.

15 al-Qaadhii Abu al-Fadhl 'Iyaadh ibn Musa ibn 'Iyadh, Masyaariq Al-Anwaar 'alaa Shahaah alAtsaar, Juz. 2, (Cairo: Daar al-Turaats, n.d.), 51.

${ }^{16}$ Manzhuur, Lisaan Al-'Arab, 535.

${ }^{17}$ Manzhuur, 536.

18 Abu al-Fidaa' Ismaa'iil ibn 'Umar ibn Katsiir, Tafsiir Al-Qur'aan al-Azhiim, ed. Saamii Muhammad al-Salaamah, Vol.8, (Riyadh: Dar Taibah for Publishing and Distribution, 1999), 26.

${ }^{19}$ Abu Ja'far Muhammad ibn Jariir al-Thabariy, Tafsiir Al-Thabariy Jaami' al-Bayaan 'an Ta'wiil Aay al-Qur'aan, ed. 'Abdullah ibn 'Abdul Muhsin Muhsin al-Turkiy, Vol. 22, (Cairo: Hajar li al-Thibaa'ah wa al-Tawzii' wa al-I'laam, 2001), 418. 
Bukhari mencatat sebuah hadist yang diriwayatkan Sayyidah 'Aisyah terkait tentang bagaimana sakit bisa menghapuskan dosa-dosa manusia sebagai berikut:

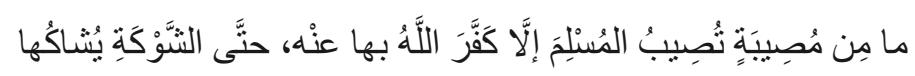

Dalam Fath al-Bari, Imam Ibn Hajar menjelaskan bahwa musibah diberikan kepada manusia dikarenakan dosa-dosa maksiat yang dilakukannya. Musibah dan/atau sakit tersebut, diberikan sebagai metode untuk menghapus dosa-dosanya tersebut. Ibn Hibban juga menambahkan, bahwa dengan melewati musibah, seorang hamba tidak hanya akan mendapatkan penghapusan dosa, namun juga meningkatnya derajat dirinya. ${ }^{20}$ Ini artinya, mengikuti pendapat di awal terkait fitrahnya Musibah, ada juga musibah yang dikenakan atas manusia sebagai ujian yang diberikan sebagai 'akibat' yang dilakukan oleh manusia itu sendiri. Konsepsi kedua ini sesuai dengan konsepsi pertama di mana Allah hanya akan memberikan musibah kecuali hamba-Nya mampu untuk mencari jawaban atau solusi akan musibah tersebut.

Jika Imam Bukhari 'merangkum' hadist-hadist terkait dengan musibah dan sakit, Imam Ibn Abu Dunya pun mencatat dalam bukunya yang berjudul Kitaab al-Maradh wa al-Kaffaraat. Dalam Kitab ini, Imam ibn Abu Dunya mencantumkan lebih dari 250an hadist yang menjelaskan bagaimana sakit memang merupakan karunia Allah SWT yang diturunkan tidak hanya melalui proses yang sederhana namun juga merupakan hasil konsekuensi dari manusia itu sendiri. Penyakit juga tidak sekedar adzab, namun juga merupakan proses dari pertaubatan manusia. ${ }^{21}$ Di antara hadist yang dicantumkan adalah sebagai berikut:

$$
\begin{aligned}
& \text { إذا ابتلى الله العبد بالسقم أرسل الله إليه ملكين, قال: اسمعا ما يقول عبدى لعوّ اده, فإن حمد الله و اثن عليه, خير اً بلغا }
\end{aligned}
$$

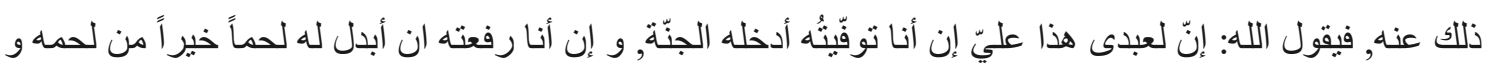

$$
\begin{aligned}
& \text { دماً خير آ من دمه و أغفر له. }
\end{aligned}
$$

Artinya: "Jikalau Allah mengkaruniakan salah seorang hamba dengan sakit, Allah akan mengirimkan padanya 2 orang malaikat. Allah kemudian berkata, 'dengarkan apa yang dia katakan atas sakit yang mengenainya itu'. Jika hamba itu bersyukur dan memuji Allah, dan kemudian dua malaikat itu melapor kepadaNya, Allah berkata, 'Sesungguhnya hamba-Ku ini adalah milik-Ku, jika kuwafatkan dia akan kumasukkan ke dalam syurga, jika kuangkat

${ }^{20}$ Imam Ahmad ibn 'Ali ibn Hajar 'Asqalaani, Fath Al-Bari Bi Syarhi Sahiih al-Imaam Abi 'Abdillah Muhammad Ibn Ismaa'il al-Bukhaari, Vol. 10, (Cairo: al-Maktabah al-Salafiyah, 2015), 106.

${ }^{21}$ Imam Ibn Abi Dunya, Kitaab Al-Maradh Wa al-Kaffaraat (Bombay: AlDarissalafiyyah, 1991). ${ }^{22}$ Dunya, 26.

Tribakti: Jurnal Pemikiran Keislaman

Volume 31, Nomor 2, Juli 2020 
(penyakitnya) dan kuganti dagingnya dengan daging yang lebih baik, dan darahnya dengan darah yang lebih baik dan kuampuni dosa-dosanya."

\section{Worldview dan Pandemi: Sebuah Konsekuensi}

Berdasarkan konsepsi Pandemi di atas, Umat Islam wajib untuk tidak hanya melihat Pandemi sebagai takdir Allah semata, yang kemudian kita lantas diam saja dan 'menerima' tanpa berbuat apa-apa. Dengan kata lain, meskipun konsepsi Pandemi memiliki dimensi 'fitrah' yang berasal dari Tuhan, manusia tetap memiliki kesempatan untuk berupaya (ikhtiyar) dalam memperjuangkan nasibnya. ${ }^{23}$ Ada dua hal terpenting yang patut kita jadikan catatan untuk refleksi; Pertama, Pandemi sudah ada semenjak zaman dahulu kala dan; Kedua, Tradisi Medis yang canggih dalam Sejarah Peradaban Islam.

Pertama, Pandemi sudah ada dan terjadi semenjak zaman dahulu kala, bahkan sebelum kelahiran Baginda Nabi Muhammad shallallahu 'alayhi wa sallam. Pandemi yang pertama adalah the plague of Justinian. Justinian merujuk kepada Kaisar Byzantium Justinian yang memerintah dalam kurun 527-565. Pandemi ini muncul pada sekitar tahun 541 di Pelusium, daerah pelabuhan di Sungai Nil di Mesir yang digunakan untuk perahu berlayar ke arah Mediterania. Penyakit misterius ini, menjarah seluruh wilayah Byzantium dan Eropa hingga Persia. Setelah 12 tahun, Pandemi ini baru bisa disembuhkan. 24

Pandemi yang kedua juga pernah terjadi di zaman Khalifah 'Umar ibn Khattab. Pandemi inilah yang biasa dikenal sebagai Thaa'uun atau Thaa'uun 'Amwaas طاعون) (عمواس). Thaa'uun 'Amwaas terjadi di tahun $18 \mathrm{H}$ atau 639 M; 'Amwaas merujuk kepada daerah berasalnya penyakit ini yang berada di wilayah Palestina hari ini. Dalam Pandemi ini, sejumlah sahabat wafat diantaranya Abu 'Ubaydah al-Jarrah, Mu'adz ibn Jabal, Yazid ibn Abi Sufyan, Harits ibn Hisyam, Suhail ibn 'Amru, 'Utbah ibn Suhayl, dan 'Amir ibn Ghilaan. ${ }^{25}$ Dalam catatan ibn Atsir, 'Umar ibn Khattab sudah berniat 'menjemput' Abu 'Ubaydah, namun diingatkan oleh 'Abdurrahman ibn 'Auf, akan hadist Nabi Muhammad Shallallallahu 'alayhi wa sallam sebagai berikut:

\footnotetext{
${ }^{23}$ Hamid Fahmy Zarkasyi, Al-Ghazali's Concept of Causality with Reference to His Interpretation of Reality and Knowledge (Kuala Lumpur: IIUM Press, 2010), 217.

${ }^{24}$ Michael W. Dols, "Plague in Early Islamic History," Journal of the American Oriental Society 94, no. 3 (July 1974): 371, https://doi.org/10.2307/600071.

${ }^{25}$ Abu al-Hasan 'Ali ibn Abi al-Karam Muhammad ibn Muhammad ibn 'Abdul Karim ibn 'Abdul Wahid al-Syaibani ibn al-Atsir, Al-Kaamil Fi al-Taarikh, ed. Abu al-Fida' 'Abdullah al-Qadhi,Vol. 211 vols. (Beirut: Daar al-Kutub al'Ilmiyyah, 1987), 399.
} 


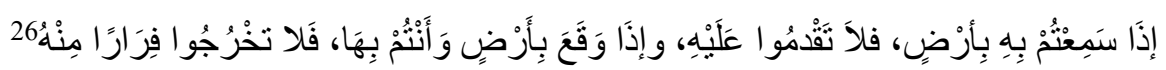

Hadist itu bermakna, "Jika kalian mendengar ada penyakit (wabah) terjadi di suatu daerah, maka janganlah memasuki daerah itu, dan jika penyakit itu terjadi di daerah kalian, maka janganlah keluar dari situ." Hadist ini mirip seperti konsep lockdown yang diperkenalkan dewasa ini terkait dengan hadirnya COVID-1927, yang dalam Bahasa Indonesia dilaksanakan dengan 'Pembatasan Sosial Skala Besar' ${ }^{28}$. Dalam penjelasan Ibn Hajar, hadist yang disanadkan kepada Usamah ibn Zaid ini terkait dengan larangan Nabi atas umatnya untuk tidak 'membahayakan diri', terutama setelah mengetahui bahwa di daerah tersebut ada penyakit yang berbahaya. ${ }^{29}$

Setelah diingatkan hadist itu, Khalifah 'Umar membatalkan niatnya untuk menyelamatkan Para Sahabat di Syam hingga rombongan pasukan meninggal dunia. Dicatat ibn Atsir, ada sekitar 25.000 umat Islam wafat di Thaa'uun 'Amwaas. ${ }^{30}$ Thaa'uun 'Amwaas mereda setelah kurang lebih setahun. Dalam kondisi umat Islam di Syam yang rawan dari serangan musuh, akhirnya Khalifah 'Umar berkunjung ke sana dan membagikan warisan kepada Umat Islam yang masih hidup. Kunjungan itu juga merupakan kunjungan Khalifah 'Umar yang terakhir ke Syam. ${ }^{31}$

Kedua, Peradaban Islam adalah Peradaban yang masyhur dengan perkembangan tekonologi dan sains yang sangat maju di masa-masa puncak keemasannya. Kemajuan tersebut, tentu saja mencakup terobosan-terobosan baru dalam bidang medis yang sebelumnya tidak pernah didapat atau ditemukan di dunia Barat. Fakta ini penting untuk terus digali dan dikaji sebagai bagian refleksi sejarah untuk memetakan kembali situasi umat Islam kekinian. Di dunia Barat, data ini seringkali 'ditutup-tutupi' atau bahkan sengaja 'dilenyapkan'; seperti yang dicatat oleh Ingrid Hehmeyer dan Aliya Khan, bahwa, “... For the most part, Western scholarship belittles the contribution of the

\footnotetext{
26 'Asqalaani, Fath Al-Bari Bi Syarhi Sahiih al-Imaam Abi 'Abdillah Muhammad Ibn Ismaa'il alBukhaari, Juz. 10, 179.

${ }^{27}$ Resnick Brian, "Italy and China Used Lockdowns to Slow the Coronavirus. Could We?," Vox, accessed May 27, 2020, https://www.vox.com/science-and-health/2020/3/10/21171464/coronavirus-uslockdown-travel-restriction-italy.

${ }^{28}$ Vina Fadhrotul Mukaromah and Virdita Rizki Ratriani, “Jokowi Putuskan Pembatasan Sosial Skala Besar, Apa Bedanya Dengan Karantina Wilayah?,” Kompas, January 4, 2020, https://www.kompas.com/tren/read/2020/04/01/064500365/jokowi-putuskan-pembatasan-sosial-skalabesar-apa-bedanya-dengan-karantina?page=all.

${ }_{29}$ 'Asqalaani, Fath Al-Bari Bi Syarhi Sahiih al-Imaam Abi 'Abdillah Muhammad Ibn Ismaa'il alBukhaari, Juz. 10, 178.

${ }^{30}$ ibn al-Atsir, Al-Kaamil Fi al-Taarikh, Juz. 2, 401.

${ }^{31}$ Abu al-Fidaa' Ismaa'iil ibn 'Umar ibn Katsiir, Al Bidayah Wa Al-Nihayah, Vol. 7, 15 vols. (Beirut: Dar El Maaref, 1990), 79.
}

Tribakti: Jurnal Pemikiran Keislaman Volume 31, Nomor 2, Juli 2020 
physicians of the Islamic world. They are usually perceived as simple purveyors of Greek science to the scholars of the Renaissance. However, the facts show otherwise.. "32 Di dalam artikelnya yang berjudul Islam's Forgotten Contributions to Medical Science, Helmeyer dan Khan sejumlah penemuan-penemuan medis yang telah sangat berpengaruh pada perkembangan kedokteran modern.

Ibn al-Haytham (354-430/ 965-1040), misalnya, di abad ke 11 menulis Kitaab alManaazhir (The Book of Optics) ${ }^{33}$ yang di abad ke 12 diterjemahkan ke Bahasa Latin dan menjadi pegangan utama Dunia Medis Internasional hingga abad ke 17. Ibn al-Nafis (607-687/ 1213-1288), memecahkan misteri 'mengapa darah manusia mengalir dari jantung kanan ke jantung kiri', yang bahkan belum bisa dipecahkan oleh Saintis Yunani lebih dari 1000 tahun sebelumnya. ${ }^{34}$ Ibn Sina (370-427/980-1037) menulis al-Qaanuun fi al-Thibb (The Canon of Medicine) ${ }^{35}$ yang menjadi rujukan utama Ensiklopedia Medis di Universitas-Universitas Eropa semenjak diterbitkannya di tahun 1020 hingga lebih abad ke 17. ${ }^{36}$ Tokoh-tokoh lainnya yang juga patut dikenal adalah al-Zahrawi (9361013). Ia menulis Kitab al-Tashriif, yang mana salah satu babnya, yaitu bab 'amal alJaraahin' (bedah/surgery) ${ }^{37}$ diterjemahkan ke Bahasa latin dan dianggap sebagai sumber studi bedah paling otoritatif di dunia selama 500 tahun. ${ }^{38}$ Dan lain sebagainya. Ini artinya, karya-karya Ulama tersebut mau tidak mau diakui sebagai sebuah 'jembatan' yang mengantarkan Peradaban Barat ke era Renaissance-nya (Kurun Abad 15-16). ${ }^{39}$

Jika rangkuman akan keagungan peradaban ini dikaji dengan cermat, sangatlah lumrah bahkan patut jika Umat Islam mentelaah kejayaan ini sebagai sebuah panduan akan 'kecerdasan ilmiah' dalam menyaksikan fenomena, yaitu dengan tetap

32 I. Hehmeyer and A. Khan, "Islam's Forgotten Contributions to Medical Science," Canadian Medical Association Journal 176, no. 10 (May 8, 2007): 1467-68, https://doi.org/10.1503/cmaj.061464.

${ }^{33}$ Hasan Ibn Haitham, Kitaab Al-Manaazhir, ed. Abdelhamid I Sabra (Kuwait: al-Silsilah alTuraatsiyyah, 1982).

34 John B West, "Ibn Al-Nafis, The Pulmonary Circulation, and The Islamic Golden Age," J Appl Physiol 105 (2008): 4.

${ }^{35}$ Abu 'Ali al-Husayn ibn 'Abdullah ibn al-Hasan ibn 'Ali ibn Sina, Al-Qaanuun Fi al-Thibb (Beirut: Dar al-Kotob al-Ilmiyah, 1999).

${ }^{36}$ Jon McGinnis, Avicenna, Great Medieval Thinkers (Oxford ; New York: Oxford University Press, 2010), 227.

${ }^{37}$ Abu al-Qasim Khalaf ibn 'Abbas al-Zahrawi al-Zahrawi, Al-Zahraawii Fii al-Thibb Li 'Amal alJaraahiin, ed. Muhammad Yasir Zakur and Muhammad Hasyim Zakur (Damaskus: Publications of the Syrian General Authority, 2006).

${ }^{38}$ The Editors of Encyclopaedia Britannica, “Abū Al-Qāsim,” Encyclopædia Britannica, July 20, 1998, https://www.britannica.com/biography/Abu-al-Qasim.

${ }^{39}$ Dag Nikolaus Hasse and Edward N. Zalta, "Influence of Arabic and Islamic Philosophy on the Latin West," The Stanford Encyclopedia of Philosophy (Spring 2020 Edition), March 2021, https://plato.stanford.edu/archives/spr2020/entries/arabic-islamic-influence. 
memperhatikan ajaran-ajaran Islam yang didasarkan dalam al-Qur'an dan Sunnah Nabi, sekaligus turut melaksanakan protokol-protokol kesehatan mengikuti aturan dan norma yang berlaku. Tradisi Intelektual inilah yang membangun Worldview seorang Muslim dalam menghadapi Pandemi sebagaimana sudah dijelaskan; tidak mendatangi kawasan terkena pandemi, diikuti dengan fakta-fakta akan perkembangan medis yang sangat hebat di dunia Islam, Kedua pijakan itu harus berjalan beriringan. Kecerdasan Umat Islam dalam menghadapi Pandemi dilihat dari bagaimana nalar saintifik harus tetap berjalan sesuai dengan konsepsi yang dikemukakan dalam pandangan hidup (Worldview) Islam sebagaimana sudah dijelaskan di atas.

\section{COVID-19 dan Teori Konspirasi}

Jika sudah sedemikian jelas penjabaran tradisi Worldview Islam dalam menyikapi Pandemi, bagaimana kemudian kaitannya dengan Teori-Teori Konspirasi terutama yang mengitari Pandemi COVID-19? Apakah dia juga bisa 'disandarkan' sebagai sebuah bagian yang membangun konsepsi pandemi dalam Worldview Islam?

Pertama, mari kita pahami apa itu 'Teori Konspirasi'; Secara historis, Teori Konspirasi berfungsi sebagai sumber kebenaran alternatif dalam menjelaskan proses geopolitik revolusioner yang ada di dunia semenjak Revolusi Prancis (1789-199). Biasanya, dia diwujudkan dengan adanya 'dugaan' atas eksistensi sebuah kontrol dunia global yang berasal dari sebuah 'komunitas rahasia' (secret societies) atau 'organisasi adidaya' (powerful organization); baik Illuminati, Freemasonry, dan lain sebagainya. Dalam penelitian Calance Madalina, meskipun tidak ada bukti yang pasti akan nyatanya gerakan ini, namun harus diakui bahwa Globalisasi adalah sebuah proses yang dilahirkan berdasarkan maksud dan kepentingan individu-individu tertentu di periode waktu yang berbeda, secara simultan, dan sistematis. ${ }^{40}$ Faktanya, kita senantiasa dikelilingi teori konspirasi dengan segenap banyak kepentingan yang menyertai, namun tidak kemudian kita mesti membenarkan semua konspirasi itu. Terkait itu, Michael Newton menulis: “... The fact that thousands of conspiracies exist and have been amply documented does not mean, of course, that every theoretical conspiracy is true. Some are absurd, transparently ridiculous, or even physically impossible. A number of the plots detailed within these pages seem to be half tawdry jest and half distilled insanity. Unfortunately

\footnotetext{
${ }^{40}$ Calance Madalina, "Globalization and the Conspiracy Theory," Procedia Economics and Finance 23 (2015): 677-81, https://doi.org/10.1016/S2212-5671(15)00474-8.

Tribakti: Jurnal Pemikiran Keislaman

Volume 31, Nomor 2, Juli 2020
} 
for the critics of "conspiratorial thinking," some of the silliest plans are also among the best-documented, confessed by their authors and verified from declassified government files...."'t1

Karen M. Douglas mencatat sejumlah konsekuensi dari teori konspirasi: Pertama, Masyarakat mampu berangkat untuk 'menantang' hierarki dominan dari sebuah sistem. Langkah ini berpotensi mendorong pemerintah untuk lebih 'transparan' dalam pemberian kebijakan publik terutama dalam pembentukan masyarakat yang demokratis. Kedua, teori-teori konspirasi biasanya berakhir dengan prasangka atau kecurigaan atas suatu golongan yang berbeda. Bagi masyarakat yang mempercayai bahwa Freemasonry adalah 'biang keladi' dari transformasi dunia global akan cenderung membenci Yahudi (Anti-Semitism). Di lain sisi, ada banyak sekali masyarakat internasional yang percaya bahwa Umat Islamlah biang teror di dunia ini, kemudian mengakitkan aksi teror kepada Umat Islam, meskipun tidak pasti Umat Islam yang melakukan aksi itu. Ketiga, teori konspirasi berpengaruh kepada hal-hal yang terkait dengan isu kesehatan seperti kontrasepsi, vaksinasi, dan konservasi alam. Keempat, teori konspirasi berpengaruh kepada sikap politik, dan; Kelima, teori konspirasi berpengaruh pada kinerja Sumber Daya Manusia di tempat-tempatnya mencari nafkah. ${ }^{42}$

Dalam konteks medis, berdasarkan teori konspirasi, masyarakat bisa menolak obat atau vaksin yang tersedia; dengan keyakinan bahwa penyakit/pandemi yang tengah berlangsung memang dimaksudkan untuk 'mengembalikan' sejumlah bagian dari dunia. ${ }^{43}$ Hal ini juga yang terjadi pada Pandemi COVID-19, di mana sejumlah konspirasi -yang lebih tepat disebut sebagai disinformasi- ${ }^{44}$ memberikan informasi yang tidak absah dan tidak bisa dipastikan kebenarannya. . Di antaranya, adalah bahwa COVID-19 dikatakan sebagai Virus yang 'bocor' dari Laboratorium di Wuhan, ${ }^{45}$ bersumber dari

${ }^{41}$ Michael Newton, The Encyclopedia of Conspiracies and Conspiracy Theories (New York: Facts on File, 2006), iv.

${ }^{42}$ Karen M. Douglas et al., "Understanding Conspiracy Theories," Political Psychology 40, no. S1 (February 2019): 3-35, https://doi.org/10.1111/pops.12568.

${ }^{43}$ Douglas et al.

${ }^{44}$ BBC Monitoring, "BBC News," China coronavirus: Misinformation spreads online about origin and scale, January 30, 2020, https://www.bbc.com/news/blogs-trending-51271037.

${ }^{45}$ Ryan Broderick, "Buzz Feed News," Scientists Haven't Found Proof The Coronavirus Escaped From A Lab In Wuhan. Trump Supporters Are Spreading The Rumor Anyway., April 22, 2020, https://www.buzzfeednews.com/article/ryanhatesthis/coronavirus-rumors-escape-lab-china-fox-newstrump. 
Yahudi, ${ }^{46}$ Muslim adalah penular COVID-19, ${ }^{47}$ hingga isu akan adanya 'Senjata Biologis'. ${ }^{48}$ Semua teori konspirasi ini sudah ditolak oleh lembaga-lembaga otoritatif terkait dengan penanganan COVID-19.

Sebagaimana sudah dikutip di atas, Globalisasi nyata terjadi ke arah kepentingan tertentu. Catatannya adalah, bahwa teori konspirasi terus berusaha bertahan dalam jangka waktu yang lama meskipun tidak memiliki bukti yang pasti; ia dibangun berdasarkan bermacam pola pemikiran yang tidak bisa dilacak kebenarannya. Sebagaimana Stephan Lewandownsky dan John Cook menulis sebagai berikut:

"Real conspiracies do exist. Volkswagen conspired to cheat emissions tests for their diesel engines. The U.S. National Security Agency secretly spied on civilian internet users. The tobacco industry deceived the public about the harmful health effects of smoking. We know about these conspiracies through internal industry documents, government investigations, or whistleblowers. Conspiracy theories, by contrast, tend to persist for a long time even when there is no decisive evidence for them. Those conspiracy theories are based on a variety of thinking patterns that are known to be unreliable tools for tracking reality. Typically, conspiracy theories are not supported by evidence that withstands scrutiny but this doesn't stop them from blossoming. For example, the widespread belief that the 9/11 terrorist attacks were an "inside job" has persisted for many years after the event.1 Decades after the fact, a vast majority of Americans believe that the government covered up the truth about the JFK assassination." 49

Ini artinya, Jika nalar saintifik manusia dibangun berdasarkan bukti-bukti argumentatif, maka teori konspirasi tidak mendukung itu. Oleh karena itulah, meskipun ada sejumlah 'fenomena yang bisa diderivasi daripadanya sumber kebenaran', Teori Konspirasi tidak akan bisa menjadi sumber kebenaran otoritatif; atau dengan kata lain, teori konspirasi hanya bisa mampu menjadi sumber kebenaran alternatif-sebagaimana sudah disinggung di atas-. Itupun dengan catatan, bahwa teori konspirasi yang disampaikan tidaklah melanggar kaidah-kaidah saintifik yang telah disepakati secara umum dan disahkan melalui protokoler maupun jalur hukum yang berlaku. Jikalau

46 Seth J. Frantzman, “The Jerusalem Post," Iran's regime pushes antisemitic conspiracies about coronavirus, March 8, 2020, https://www.jpost.com/Middle-East/Iran-News/Irans-regime-pushesantisemitic-conspiracies-about-coronavirus-620212.

${ }^{47}$ Chantal Da Silva, "India's Coronavirus Outbreak Stokes Islamophobia as Muslims Blamed for Spreading Infection,” April 3, 2020, https:/www.newsweek.com/indias-coronavirus-outbreak-stokesislamophobia-muslims-blamed-spreading-infection-1496011.

${ }^{48}$ Charles Calisher et al., "Statement in Support of The Scientists, Public Health Professionals, and Medical Professionals of China Combatting COVID-19," The Lancet 395, no. 10226 (March 2020): e4243, https://doi.org/10.1016/S0140-6736(20)30418-9.

${ }^{49}$ Stephan Lewandowsky and John Cook, The Conspiracy Theory Handbook, 2020.

Tribakti: Jurnal Pemikiran Keislaman

Volume 31, Nomor 2, Juli 2020 
demikian, maka Worldview Islam tidaklah mampu dibangun melalui 'jalur' Teori Konspirasi; begitupun sebaliknya, Teori Konspirasi tidaklah dianggap sebagai bagian dari tradisi intetelektual Islam yang membangun Worldview Islam.

\section{New Normal Paska Pandemi: Sebuah Catatan}

Korinne Griffith mendefinisikan New Normal sebagai sebuah upaya dalam rangka 'mengembalikan situasi usai pandemi kembali ke normal': “...This includes limiting person-to-person contact, like handshakes and hugs. Additionally, maintaining distance from others..." 50 Secara umum, New Normal masih sangat terkait dengan protokol kesehatan global dalam rangka membendung penyebaran COVID-19 yang masif disuarakan WHO. ${ }^{51}$ Yang membedakannya, New Normal tidaklah lagi dilakukan dalam bentuk 'PSBB' namun melaksanakan kehidupan 'normal' dengan sejumlah protokol kesehatan seperti: mengatur jadwal jam kerja, membatasi kerumunan sosial secara fisk (physical distancing), peningkatan fasilitas hidup bersih dan sehat seperti lokasi cuci tangan dengan sabun, dan lain sebagainya. Dalam konteks Indonesia, Langkah ini telah dideklarasikan dalam Surat Keputusan Menteri Kesehatan Republik Indonesia No. HK.01.07-MENKES-328-2020 tentang Panduan Pencegahan Pengendalian COVID-19 di Perkantoran dan Industri. ${ }^{52}$

Dalam surat edaran tersebut, redaksi New Normal termaktub di 'Latar Belakang' sebagaimana berikut:

“...Peraturan Pemerintah Nomor 21 Tahun 2020 tentang Pembatasan Sosial Berskala Besar Dalam Rangka Percepatan Penanganan Corona Virus Disease 2019 (COVID-19) telah menyatakan bahwa Pembatasan Sosial Berskala Besar (PSBB) dilakukan salah satunya dengan meliburkan tempat kerja. Namun demikian dunia kerja

tidak mungkin selamanya dilakukan pembatasan, roda perekonomian harus tetap berjalan, untuk itu pasca pemberlakuan PSBB dengan kondisi pandemi COVID-19 yang masih berlangsung, perlu dilakukan upaya mitigasi dan kesiapan tempat kerja seoptimal mungkin sehingga dapat beradaptasi melalui perubahan pola hidup pada situasi COVID-19 (New Normal). Dengan menerapkan panduan ini diharapkan dapat meminimalisir risiko dan dampak pandemi COVID-19 pada tempat kerja

50 Korinne Griffith, "The 'New Normal' after Coronavirus," May 1, 2020, https://www.ksn.com/news/capitol-bureau/the-new-normal-after-coronavirus/.

${ }^{51}$ WHO Indonesia, "Coronavirus Disease 2019 (COVID-19) Situation Report -10" (World Health Organization Indonesia, n.d.), https://www.who.int/docs/default-source/searo/indonesia/covid19/whosituation-report-10.pdf?sfvrsn=a9ceb157_2.

52 “KMK No. HK.01.07-MENKES-328-2020 Tentang Panduan Pencegahan Pengendalian COVID19 Di Perkantoran Dan Industri,” n.d., http://promkes.kemkes.go.id/kmk-no-hk0107-menkes-328-2020tentang-panduan-pencegahan-pengendalian-covid-19-di-perkantoran-dan-industri. 
khususnya perkantoran dan industri, dimana terdapat potensi penularan COVID-19 akibat berkumpulnya sejumlah/banyak orang dalam satu lokasi." 53

Berdasarkan Dokumen ini, masyarakat dituntut -mau ataupun tidak maumerespons perkembangan pandemi COVID-19 secara seksama dan komprehensif, terutama terkait dengan relasi yang ditimbulkan antara pandemi dengan kesenjangan ekonomi. Penting untuk mencatat, bahwa dalam laporan per tanggal 3 Juni 2020, Pemerintah Indonesia mendapatkan 28,233 kasus COVID-19; 1,698 di antaranya meninggal dunia dengan jumlah 8,406 pasien sembuh di seluruh Indonesia. ${ }^{54}$ Dalam upaya-upaya “...memutus mata rantai penularan Corona Virus Disease 2019 (COVID19)..."55 di berbagai aspeknya, sekaligus “... tetap mendukung keberlangsungan perekonomian...", 56 kerja sama akan semua pihak sudah barang tentu dibutuhkan. Solusi akan Pandemi COVID-19 tidak akan mampu dicapai dengan maksimal kecuali juga dengan mengerahkan aspek ekonomi sebagai elemen krusial dalam rangka mencapai tujuan itu. Umat Islam, berbekal Worldview yang telah dikonsepsikan di atas, perlu untuk mencermati konsep Pandemi secara teliti mengikuti dokumen tersebut agar maslahat kesehatan Umat dan Bangsa Indonesia dapat segera terealisasikan.

\section{Kesimpulan}

Umat Islam yang diharap senantiasa cerdas dalam melihat fenomena tentu harus menyikapi Pandemi sebagaimana adanya sesuai dengan pandangan hidup (Worldview) Islam. Pertama, dia adalah sunnatullah yang telah ditetapkan Allah; baik sebagai suratan takdir yang ada sejak zaman azali, ataupun kejadian yang bersumber dari kesalahankesalahan manusia. Kedua, Umat Islam dituntut selalu melaksanakan protokoler hidup sehat berlandaskan kejayaan umat Islam di masa lampu dalam konteks kekinian, terutama mengikuti perkembangan teknologi medis modern. Ketiga, teori-teori konspirasi dalam Pandemi terutama COVID-19 sepatutnya dihindari dan tidak digunakan sebagai sumber utama dalam membaca fenomena. Dalam konteks NeW Normal pun, kesiapan-kesiapan pribadi seorang Muslim sebagai Warga Negara dituntut

53 “KMK No. HK.01.07-MENKES-328-2020 Tentang Panduan Pencegahan Pengendalian COVID19 Di Perkantoran Dan Industri."

${ }^{54}$ WHO Indonesia, "Coronavirus Disease 2019 (COVID-19) Situation Report -10."

55 "KMK No. HK.01.07-MENKES-328-2020 Tentang Panduan Pencegahan Pengendalian COVID19 Di Perkantoran Dan Industri."

56 “KMK No. HK.01.07-MENKES-328-2020 Tentang Panduan Pencegahan Pengendalian COVID19 Di Perkantoran Dan Industri." 
selalu mampu menyesuaikan konsep Pandemi dalam Worldview Islam berdasarkan protokol Pemerintah yang telah disampaikan di Surat Keputusan Menteri Kesehatan Republik Indonesia No. HK.01.07-MENKES-328-2020.

Menyikapi itu, sekiranya penting terutama bagi para Peneliti dalam bidang Studi Agama agar senantiasa meningkatkan kajian-kajian interdispliner dengan fokus kesehatan sebagai topiknya. Pandemi COVID-19 menunjukkan bagaimana Narasi Keagamaan memiliki peran yang sangat penting dalam membangun sudut pandang masyarakat dalam melihat Pandemi bukan hanya sekedar fenomena kealaman yang 'diterima' begitu saja, namun juga dihadapi dengan sepenuh kekuatan dan potensi manusia. Dalam konteks Worldview, ajaran-ajaran keagamaan penting ditransformasikan sebagai panduan pandangan umat Manusia dalam menghadapi Pandemi yang masih akan terus berlanjut - tanpa kita ketahui kapan ia akan berakhir.

\section{Daftar Pustaka}

'Asqalaani, Imam Ahmad ibn 'Ali ibn Hajar. Fath Al-Bari Bi Syarhi Sahiih al-Imaam Abi 'Abdillah Muhammad Ibn Ismaa'il al-Bukhaari. Cairo: al-Maktabah alSalafiyah, 2015.

Atsir, Abu al-Hasan 'Ali ibn Abi al-Karam Muhammad ibn Muhammad ibn 'Abdul Karim ibn 'Abdul Wahid al-Syaibani ibn al-. Al-Kaamil Fi al-Taarikh. Edited by Abu al-Fida' 'Abdullah al-Qadhi. 11 vols. Beirut: Daar al-Kutub al'Ilmiyyah, 1987.

Attas, Syed Muhammad Naquib al-. Prolegomena to The Metaphysics of Islam. Kuala Lumpur: International Institute of Islamic Thought and Civilization (ISTAC), 1995.

BBC Monitoring. "BBC News." China coronavirus: Misinformation spreads online about origin and scale, January 30, 2020. https://www.bbc.com/news/blogstrending-51271037.

Brian, Resnick. "Italy and China Used Lockdowns to Slow the Coronavirus. Could We?" Vox. Accessed May 27, 2020. https://www.vox.com/science-andhealth/2020/3/10/21171464/coronavirus-us-lockdown-travel-restriction-italy.

Broderick, Ryan. “Buzz Feed News.” Scientists Haven’t Found Proof The Coronavirus Escaped From A Lab In Wuhan. Trump Supporters Are Spreading The Rumor Anyway., April 22, 2020. https://www.buzzfeednews.com/article/ryanhatesthis/coronavirus-rumors-escapelab-china-fox-news-trump.

Calisher, Charles, Dennis Carroll, Rita Colwell, Ronald B Corley, Peter Daszak, Christian Drosten, Luis Enjuanes, et al. "Statement in Support of The Scientists, 
Public Health Professionals, and Medical Professionals of China Combatting COVID-19." The Lancet 395, no. 10226 (March 2020): e42-43. https://doi.org/10.1016/S0140-6736(20)30418-9.

Da Silva, Chantal. "India's Coronavirus Outbreak Stokes Islamophobia as Muslims Blamed for Spreading Infection," April 3, 2020. https://www.newsweek.com/indias-coronavirus-outbreak-stokes-islamophobiamuslims-blamed-spreading-infection-1496011.

Dols, Michael W. "Plague in Early Islamic History." Journal of the American Oriental Society 94, no. 3 (July 1974): 371. https://doi.org/10.2307/600071.

Douglas, Karen M., Joseph E. Uscinski, Robbie M. Sutton, Aleksandra Cichocka, Turkay Nefes, Chee Siang Ang, and Farzin Deravi. "Understanding Conspiracy Theories." Political Psychology 40, no. S1 (February 2019): 3-35. https://doi.org/10.1111/pops.12568.

Dunya, Imam Ibn Abi. Kitaab Al-Maradh Wa al-Kaffaraat. Bombay: AlDarissalafiyyah, 1991.

Frantzman, Seth J. “The Jerusalem Post.” Iran's regime pushes antisemitic conspiracies about coronavirus, March 8, 2020. https://www.jpost.com/Middle-East/IranNews/Irans-regime-pushes-antisemitic-conspiracies-about-coronavirus-620212.

Griffith, Korinne. "The 'New Normal' after Coronavirus," May 1, 2020. https:/www.ksn.com/news/capitol-bureau/the-new-normal-after-coronavirus/.

Haitham, Hasan Ibn. Kitaab Al-Manaazhir. Edited by Abdelhamid I Sabra. Kuwait: alSilsilah al-Turaatsiyyah, 1982.

Hasse, Dag Nikolaus, and Edward N. Zalta. "Influence of Arabic and Islamic Philosophy on the Latin West." The Stanford Encyclopedia of Philosophy (Spring 2020 Edition), March 2021. https://plato.stanford.edu/archives/spr2020/entries/arabicislamic-influence.

Hehmeyer, I., and A. Khan. "Islam's Forgotten Contributions to Medical Science." Canadian Medical Association Journal 176, no. 10 (May 8, 2007): 1467-68. https://doi.org/10.1503/cmaj.061464.

'Iyadh, al-Qaadhii Abu al-Fadhl 'Iyaadh ibn Musa ibn. Masyaariq Al-Anwaar 'alaa Shahaah al-Atsaar. Cairo: Daar al-Turaats, n.d.

Izutsu, Toshihiko. Ethico-Religious Concepts in the Qur'an. Montreal: McGill-Queen's University Press, 2002.

Kant, Immanuel. Critique of Judgment. Edited by Werner S. Pluhar. Indianapolis: Hackett Publishing Company, 1987.

Katsiir, Abu al-Fidaa' Ismaa'iil ibn 'Umar ibn. Al Bidayah Wa Al-Nihayah. 15 vols. Beirut: Dar El Maaref, 1990. 
- Tafsiir Al-Qur'aan al-Azhiim. Edited by Saamii Muhammad al-Salaamah. Riyadh: Dar Taibah for Publishing and Distribution, 1999.

“KMK No. HK.01.07-MENKES-328-2020 Tentang Panduan Pencegahan Pengendalian COVID-19 Di Perkantoran Dan Industri," n.d. http://promkes.kemkes.go.id/kmkno-hk0107-menkes-328-2020-tentang-panduan-pencegahan-pengendalian-covid19-di-perkantoran-dan-industri.

Kuhn, Thomas S. The Structure of Scientific Revolutions. Chicago: The University of Chicago Press, 1996.

Lewandowsky, Stephan, and John Cook. The Conspiracy Theory Handbook, 2020.

Madalina, Calance. "Globalization and the Conspiracy Theory." Procedia Economics and Finance 23 (2015): 677-81. https://doi.org/10.1016/S2212-5671(15)00474-8.

Manzhuur, Abu al-Fadhl Jamaal al-Diin Muhammad Muhammad ibn Mukrim ibn. Lisaan Al-'Arab. 15 vols. Beirut: Daar Shaadir, 2010.

Maududi, Sayyid Abul A'la al-Mawdudi al-. Islamic Way of LIfe. Riyadh: International Islamic Publishing House, 1997.

McGinnis, Jon. Avicenna. Great Medieval Thinkers. Oxford ; New York: Oxford University Press, 2010.

Mukaromah, Vina Fadhrotul, and Virdita Rizki Ratriani. "Jokowi Putuskan Pembatasan Sosial Skala Besar, Apa Bedanya Dengan Karantina Wilayah?” Kompas, January 4, 2020. https://www.kompas.com/tren/read/2020/04/01/064500365/jokowiputuskan-pembatasan-sosial-skala-besar-apa-bedanya-dengankarantina?page $=$ all.

Newton, Michael. The Encyclopedia of Conspiracies and Conspiracy Theories. New York: Facts on File, 2006. http://choicereviews.org/review/10.5860/CHOICE.434414.

Portaq, Miquel, Sander Greendland, and John M. Last, eds. Dictionary of Epidemiology. 5th ed. New York: Oxford University Press, 2008.

Principles of Epidemiology in Public Health Practice An Introduction to Applied Epidemiology and Biostatistics O. 3rd ed. Georgia: U.S. Department of Health and Human Services Centers for Disease Control and Prevention (CDC) Office of Workforce and Career Development (OWCD) Career Development Division (CDD), 2012.

Quthb, Sayyid. Khasaaish Al-Tashawwur al-Islaamiy. Dar El Shorouk, n.d.

Sina, Abu 'Ali al-Husayn ibn 'Abdullah ibn al-Hasan ibn 'Ali ibn. Al-Qaanuun Fi alThibb. Beirut: Dar al-Kotob al-Ilmiyah, 1999.

Smart, Ninian. The World's Religions. Cambridge: Cambridge University Press, 1998.

Stausberg, Michael, and Steven Engler, eds. The Routledge Handbook of Research Methods in The Study of Religion. London ; New York: Routledge, 2011. 
Thabariy, Abu Ja'far Muhammad ibn Jariir al-. Tafsiir Al-Thabariy Jaami' al-Bayaan 'an Ta'wiil Aay al-Qur'aan. Edited by 'Abdullah ibn 'Abdul Muhsin Muhsin alTurkiy. Cairo: Hajar li al-Thibaa'ah wa al-Tawzii' wa al-I'laam, 2001.

The Editors of Encyclopaedia Britannica. "Abū Al-Qā sim.” Encyclopædia Britannica, July 20, 1998. https://www.britannica.com/biography/Abu-al-Qasim.

West, John B. "Ibn Al-Nafis, The Pulmonary Circulation, and The Islamic Golden Age." J Appl Physiol 105 (2008): 4.

WHO Indonesia. “Coronavirus Disease 2019 (COVID-19) Situation Report -10.” World Health Organization Indonesia, n.d. https://www.who.int/docs/defaultsource/searo/indonesia/covid19/who-situation-report-10.pdf?sfvrsn=a9ceb157_2.

Zahrawi, Abu al-Qasim Khalaf ibn 'Abbas al-Zahrawi al-. Al-Zahraawii Fii al-Thibb Li 'Amal al-Jaraahiin. Edited by Muhammad Yasir Zakur and Muhammad Hasyim Zakur. Damaskus: Publications of the Syrian General Authority, 2006.

Zarkasyi, Hamid Fahmy. Al-Ghazali's Concept of Causality with Reference to His Interpretation of Reality and Knowledge. Kuala Lumpur: IIUM Press, 2010. 